\title{
MORPHOLOGICAL AND PATHOLOGICAL STUDIES ON A FILICOLLIS SPECIES (ACANTHOCEPHELA) PARASITIZED SOME AQUATIC BIRDS AT PORT SAID GOVERNORAT
}

\author{
M.W.Ghattas* and M.M.Hanafy** \\ *Port Said, Provincial Laboratory Animal Health Research Institute. \\ **Animal Health Research Institute, Dokki, Giza - Egypt.
}

\begin{abstract}
The present study was planned to identify the Acanthocephalan parasitic agents and characterization of the histopathological changes in the digestive tract. $2.35 \%$ of the examined birds were found parasitized with both mature and immature stages of Acanthocephala. They are attached to the mucosal tissues of the digestive tract by their spiny proboscis.The sex of the adult filicollis is clearly distinguishable, they have a globular bulb proboscis armed with many hooks that are arranged radially (Yamaguti, 1963) or in a star shaped pattern at the apex of the proboscis (Soulsby, 1968). The present study was the first record of filicollis species in aquatic birds examined around shores of El Manzala Lake in Port Said Province and also new host record as well.
\end{abstract}

\section{INTRODUCTION}

About 1000 species of Acanthocephalan worms had been described, all are endoparasites which are believed to attain maturity in the alimentary tract of vertebrates(Schmidt, 1969). Acanthocephela of family Filicollidae (Petrotschenko, 1956) contain two genera Filicollis; (Luhe, 1911) and Parafilicollis (Yamaguti, 1963). Yamaguti, 1963 retained filicollidae but correctly transferred its genera to Echinorhynchide, (Southwell and 
Macfie , 1925). He rejected both Parafilicollis and Profilicollis and instead elevated the subgenus Falsifilicollis (Webster, 1948). Filicollidae are parasites of aquatic birds identified from Fulica atra atra, Gallinula chloropus chloropus and Anas crecca crecca (Petrova and Vasilev, 1984 and Dimitrova and Genov,1992). This polymorphid Palaeacanthocephela with long neck was studied in naturally infected domestic ducks (Taraschewski and Hofmann, 1991). Although many surveys were carried out to investigate the parasitic fauna of native and migrant birds in Egypt (Looss, 1896; Ward, 1956; Selim and El-Kassaby, 1965; Hegazy,1978 and Ashmawy and El-Sokkary,1991); yet non of the recorded parasites of genus filicollis.

\section{MATERIALS AND METHODS}

Total of 212 aquatic birds (112 Fulica atra atra, 67 Gallinula choropus chloropus and 33 Anas crecca crecca) were collected during the period from November 2003 till April 2004. Birds were recently captured by trapping, netting and shooting from the different parts of the shores of EL Manzala Lake near Port Said Governorate. Post mortum examination was done carefully to detect any clinical signs and the gross pathological lesions in the alimentary tract. Each bird was dissected separately and examined for Acanthocephalan parasites. The detected worms were carefully washed with PBS, then gently pressed between two glass slides and fixed in $10 \%$ formol saline for 24 hours. Fixed worms were stained in acetic acid alum carmine, dehydrated through a graded series of $70 \%, 80 \%, 95 \%$ and absolute ethanol and transferred to xylene. Finally, worms were mounted in Canada balsam according to the technique described by Ash and Orihel,1987 and identified according to Yamaguti, 1963 and McDonald, 1988. The Histopathological examination were done for small portions of the alimentary tract that were impact with the parasites and fixed in $10 \%$ neutral buffer formalin, embedded in 
paraffin, sectioned at 4-5 um and stained with heamatoxylin and eosin according to the technique descried by Carleton,1978.

\section{RESULTS}

Out of 212 aquatic birds examined,5(2.35\%)were found parasitized with both mature and immature stages of Acanthocephala.

\section{Postmortum examination (PM):}

Examination of the alimentary tract revealed enlargement with several nodules at an average of 6 - 10 nodules / bird were seen along the intestinal tract (Fig.1B, C). The wall of the intestine of the parasitized birds appeared so thin and worm out, sometimes, perforation as well as obstructions due to heavy infestations with the parasites were also commonly seen. The nodules were round in shape, hard in consistency. Precise examination of these intestinal lesions revealed the presence of long plump worms of $1-2 \mathrm{~cm}$ in length with thick integument, firmly attached to the intestinal wall. Each nodule contained a globular bulb proboscis with long, slender neck and free trunck in the lumen of the intestine (Fig.1a.D).

\section{Identification of the detected worms:}

Phylum : Acanthocephela (Rudolphi, 1808).

Order : Palaeacanthocephala (Meyer, 1931).

Class : Echinorhynchida (Southwell and Macfie, 1925).

Family : Filicollidae (Petroschenko, 1958).

Genus : Filicollis (Luhe, 1911).

Male:

$\overline{\overline{\text { Kafr El-Sheikh Vet. Med. J. Vol. } 2 \text { No. } 2 \text { (2004) }}}$ 
The body was somewhat smaller measuring 7.2 - $8.5 \mathrm{~mm}$ in length, 1.5 - $1.9 \mathrm{~mm}$ in width, had a white colour with thick integument. On the anterior, they had globular bulb proboscis(Fig.2f and plate1A).The hooks of the proboscis were numerous and symmetrically arranged in 18 longitudinal rows. Each was provided with 10-11 hooks each up to 41um long, the blades of the hooks were very sharp, pointed and their roots were simple (Fig.2h).The proboscis receptacle was double walled usually long and narrow.The anterior part of the body is armed with small spines. There are two, long, slender and digitiform lateral lemnisci at the base of the neck measuring 2.0-0.4 mm (Fig.2f). In the midregion of the body, two contiguous testes were arranged one behind the other, proximal testis measured $0.52 \times 0.33 \mathrm{~mm}$, while the distal one measured $0.50 \times 0.36 \mathrm{~mm}$. Posterior to the testes, four cement glands reniform in shape and pouring their secretion into a common reservoir located at the posterior end and jointed with the bursa at its distal end (Fig.3k). Right ejaculatory duct measured $3.21 \times 0.19 \mathrm{~mm}$ while the left one measured $3.21 \times 0.21 \mathrm{~mm}$ (Fig.3j and plate 1B).

\section{Female:}

The body was larger than the males measuring 14-25mm long,yellow in colour with thick integument. Worms had a long slender neck. The proboscis forms a globular bulb measuring 2-4 mm in diameter (Fig.2g). The hooks on the proboscis apex were radially arranged or arranged in a star shaped pattern(Fig.4 and plate1F). They were symmetrically arranged in 20 longitudinal rows, each was provided with 8 - 10 hooks. Also, there were two long, slender and digitiform lateral lemnisci at the base of the neck. Uterus was very long, posterior end obtuse with subterminal reproductive opening ( Fig.3I ) . The body cavity was filled with eggs of oval shaped measuring 59 - 71um long x18 - 24 um wide without projection of the middle shell (Fig.2e and plate $1 \mathrm{E}$ ). Genital pore was terminal in both sexes (Fig.3I and plate1C).

\section{Histopathological results:}


The histopathological reaction was related to the intensity of -infestation and the depth of proboscis penetration. At the point of proboscis attachment, severe hemorrhages and epithelial damage were recorded; some slides showed proboscis extension through the epithelium into submucosa with limited hemorrhages, connective tissue fibers were recorded around the cross section of worms (Fig.5O). In some sections, the neck and proboscis penetrated the intestinal wall and surrounded by compact rounded fibrous connective tissue with fibroblast and different types of inflammatory cells with characteristic giant cells (Fig.5P). In most slides, all layers of the intestinal wall were penetrated by proboscis, bulb and neck of the worm (Fig.5q). While the trunck remain in the lumen (Fig.6r). Leading to pressure atrophy of the epithelial cells adjacent and localized inflammation. At the point where the epithelial cells were absent from intestinal mucosa, there was a marked cellular infiltration, edema and mononuclear cells with eosinophilic cells were recorded in four cases. Erosion of the intestinal epithelium where it is contact with the trunck of worm (Fig.6s). In most cases, the intestinal villi were either sloughing or shorten with compressed state (Fig.6t). Otherwise degeneration and necrosis of its epithelial lining.

Goblet cells were abundant in the villi, in case of direct contact with the worm. In two examined cases, there was incomplete penetration of the presoma of Acanthocephalan through the intestinal wall with focal areas of inflammatory cells in both presomal sides (Fig.7u).It has been recorded that in few slides, the morphology of giant cells of the muscles which were located in the proesomal root of young Acanthocephela and are apparently similar with retinocular cells (rod and cone cells of eye (Fig.7v). 


\section{DISCUSSION}

Depending on the keys by Yamaguti, 1963 and McDonald, 1988; it is clear that, the Acanthocephala encountered in the present study from the small intestine of coot (Fulica atra atra), moorhen (Gallinula chloropus chloropus ) and Teal(Anas crecca crecca)captured from the shores of El Manzala lake around Port Said Province, Egypt could be identified as Filicollis species. On reviewing the literature, it was found that, the present work was the first record of Filicollis species infesting aquatic birds in this area of investigation and also new host record as well. Filicollis species was detected in 5 out of 212 (2.35\%) aquatic birds examined in Port Said Province, Egypt, in accordance with the findings of Petrova and Vasilev, 1984 as they were found Acanthocephela in 15 out of 624 (2.40 \%) wild birds examined in Bulgaria; also they found Filicollis anatis in Anas platyrhynchos and Gallinula chloropus chloropus. Our findings were coincided with Dimitrova and Genov, 1992 who found Filicollis anatis in Anas clypeata,A.querquedula,Fulica atra atra and Gallinula chloropus chloropus examined in Bulgarian Black sea coast and lower than the incidence of Ashmawy and El Sokkary, 1991; who found Acanthocephela in 80.8 \% Egyptian birds (centropus senegalenses aegypticus) examined in Edfina Behera Province, Egypt. The identification of Filicollis species was obtained on the basis of morp-hometric characteristics mainly, the number of hooks on the proboscis and the number and arrangement of rows of hooks (Petrochenko, 1971).

Family Filicollidae was established by Petroschenko, 1956 as parasite of aquatic birds,much of the confusion that has surrounded those of Acanthocephala with a long neck and ovoid or spheroid proboscis, in 
1958 he given a key to differentiate genus Filicollis by their marked sexual dimorphism and pyriform cement glands.

The identified Filicollis species presents the typical generic charact-eristics related to the measurements of the body,eggs and internal features, also the shape and distribution of the proboscis hooks were similar with the descriptions of Yamaguti,1963; Soulsby,1968; Soulsby,1982 and McDonald,1988.

When the present specimens were compared with the previously reported Filcollis anatis,(Soulsby, 1968 and Atrashkevich, 1982); it was found to be distinct by the number of longitudinal rows of hooks(20) and the number of hooks on each row(10-11)also the present specimens were somewhat longer but similar on their radially arrangement, long and slender lemnisci and the number and shape of cement glands.

The proboscis of both sexes in the present species forms a globular bulb on the apex of which the hooks were arranged radially,in accordance with Yamaguti, 1963 and in contrary with Van cleave, 1920 ;Soulsby, 1968 and Taraschewski, 2000 who stated that, only females posses a bulbous with a flat proboscis forming the apical tip of the bulb. The present paper stopped the identification of the detected specimen at the generic level waiting for further work on the life cycle of this parasite.

Wild birds have been fed a diet containing a high proportion of arthropods, fish, mollusca, reptiles and rodents; most of them acting as intermediate host for certain helminthes. This means that birds might carried a high parasitic disease fauna(EL Seify and Abd EL Fattah 1996). 
The microscopical examination of the results was related to the intensity of infestation and the depth of proboscis penetration as proved by Meilssa et. Al., 1981. All the histopathological results were coincided with Hayunga, 1979; Ashmawy and EI Sokkary 1991 and Nikishin, 2000.

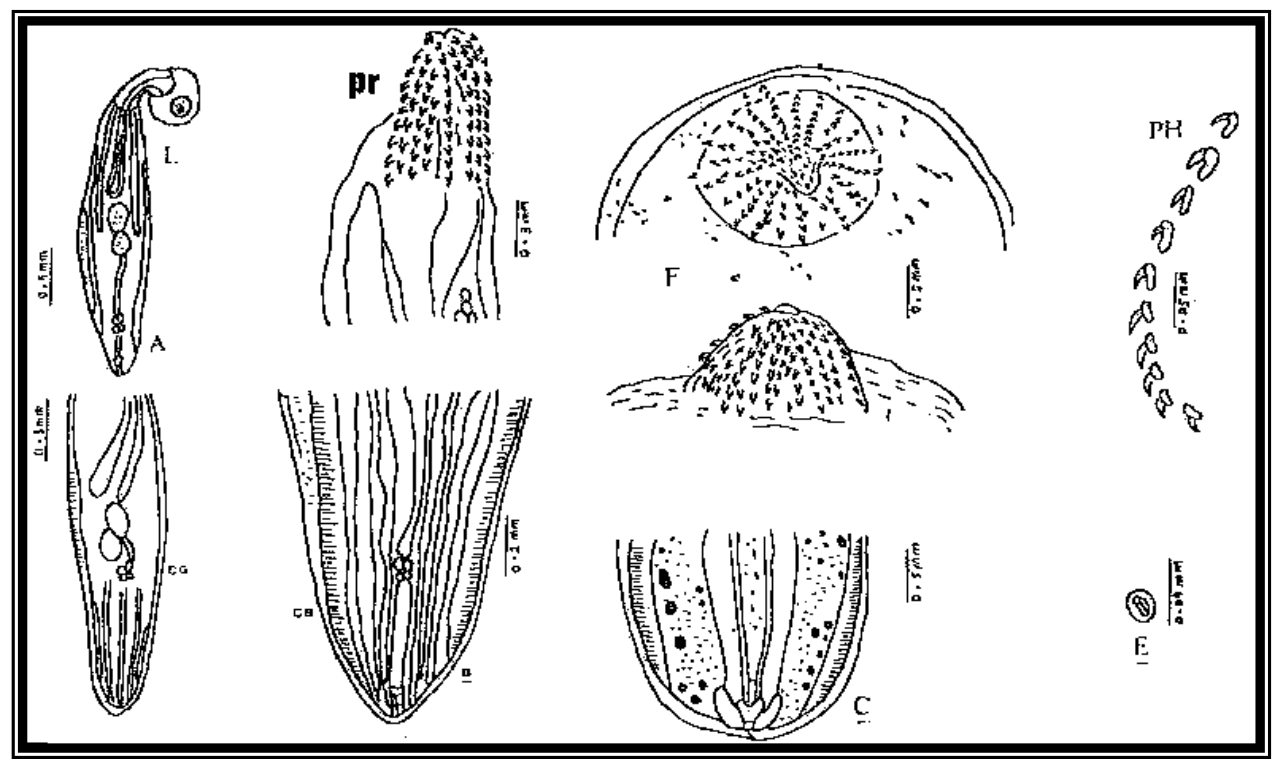

Plate. 1: Filicollis species A- Adult male Pr- Proboscis L- Lemnisci CGCement glands $\mathrm{PH}$ - Proboscis hooks CB- Copulatory bursa B- Posterior portion of male C-Posterior portion of female F-Proboscis hooks of female EEgg. 

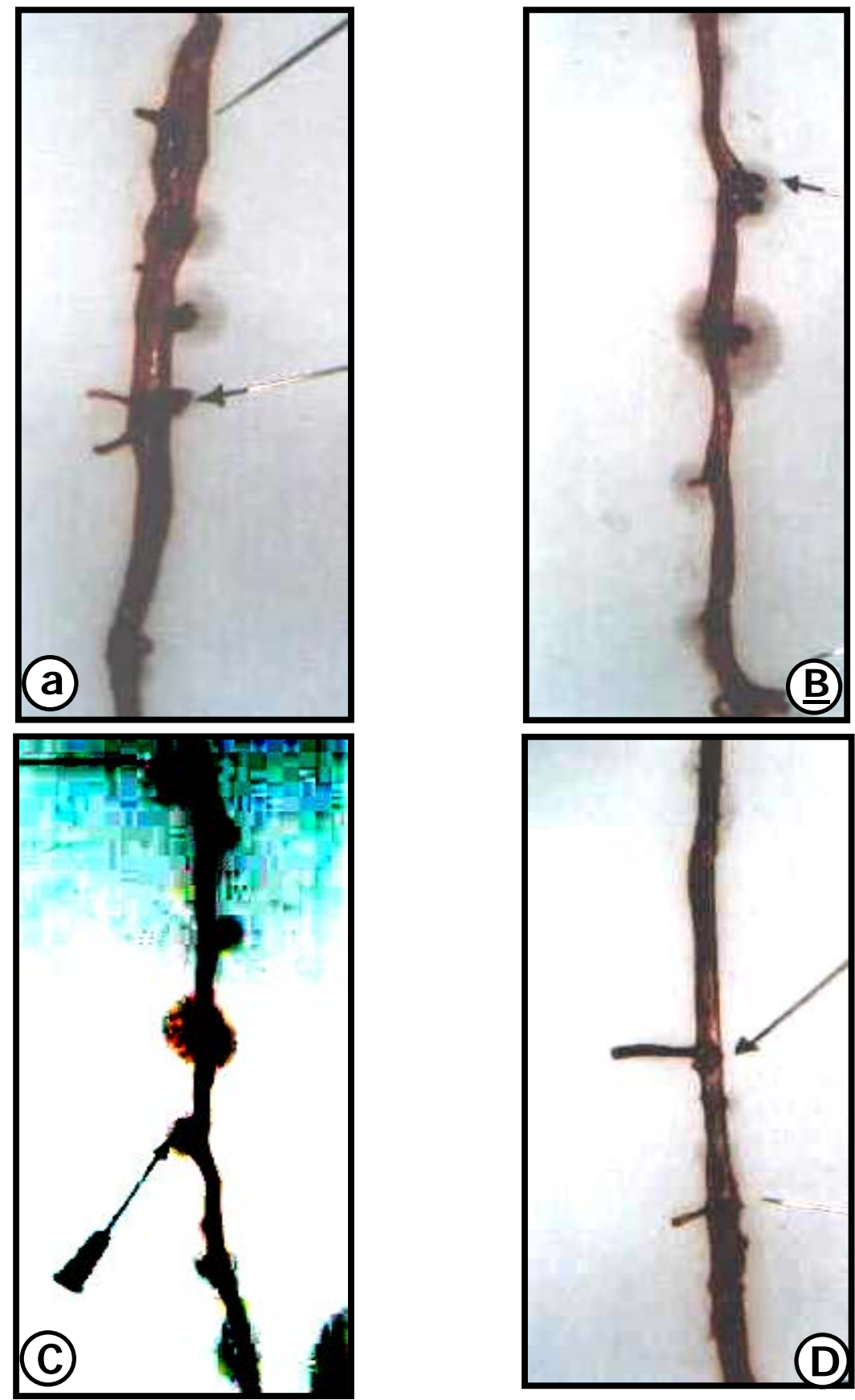

Fig(1):Gross macroscopic appearance of Acanthocephelan parasitic infestation and nodular lesions in the intestinal wall of the examined aquatic birds. 

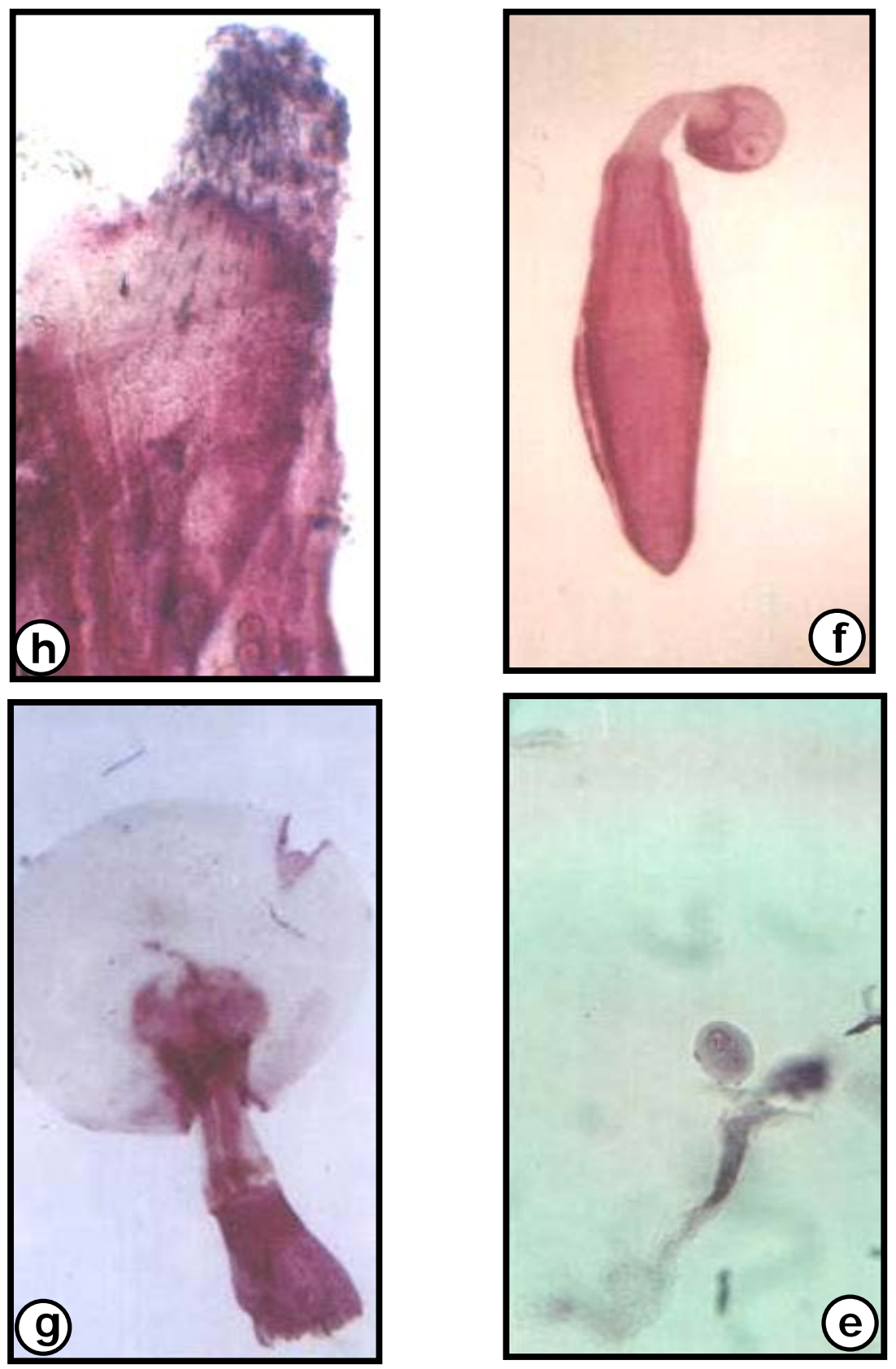

Fig (2): f- Whole body of male h- Proboscis of male e- Egg g- Globular bulb proboscis of female. 

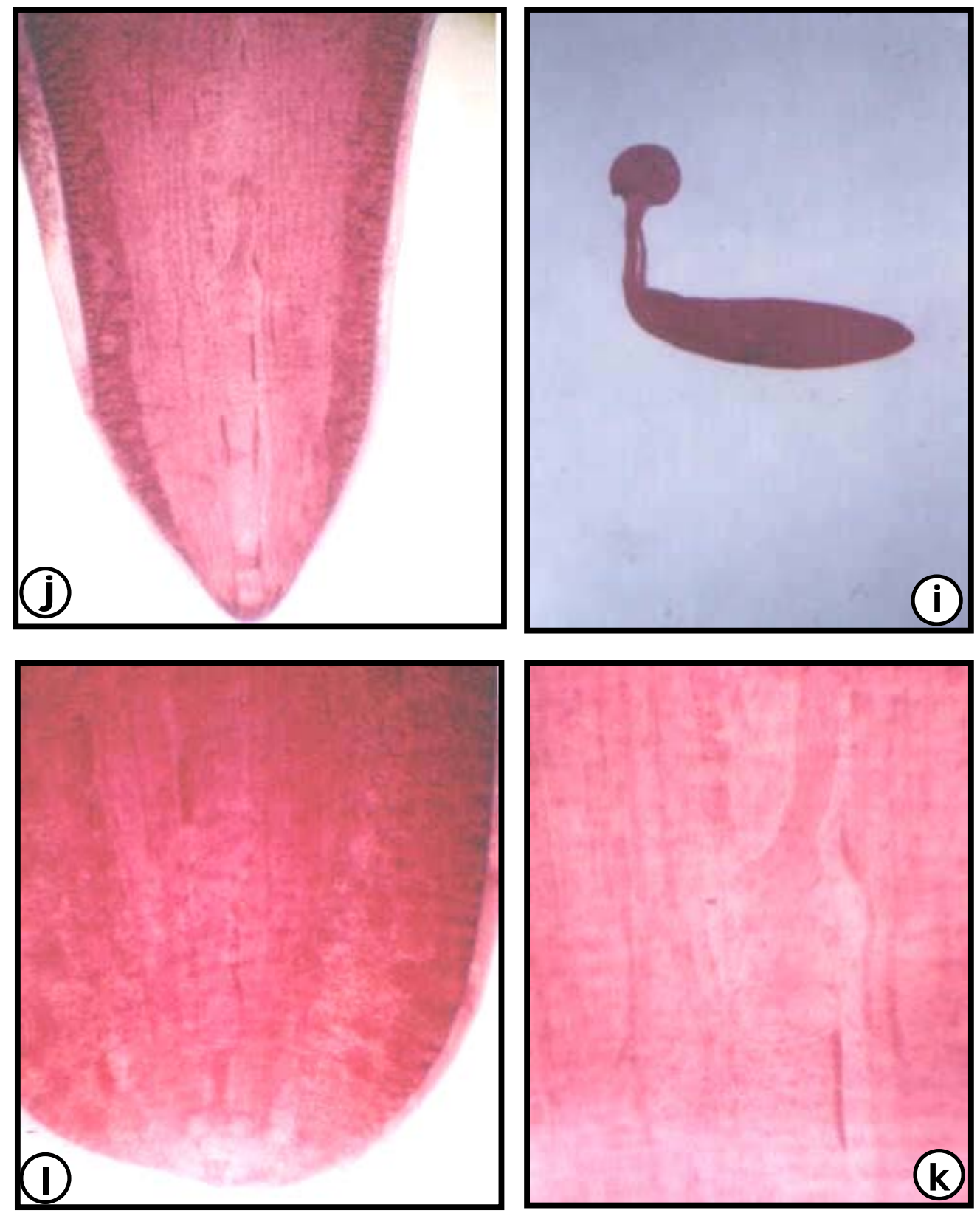

Fig (3): j- Posterior portion of male k - Cement glands I- Posterior portion of female.

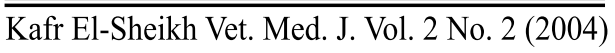



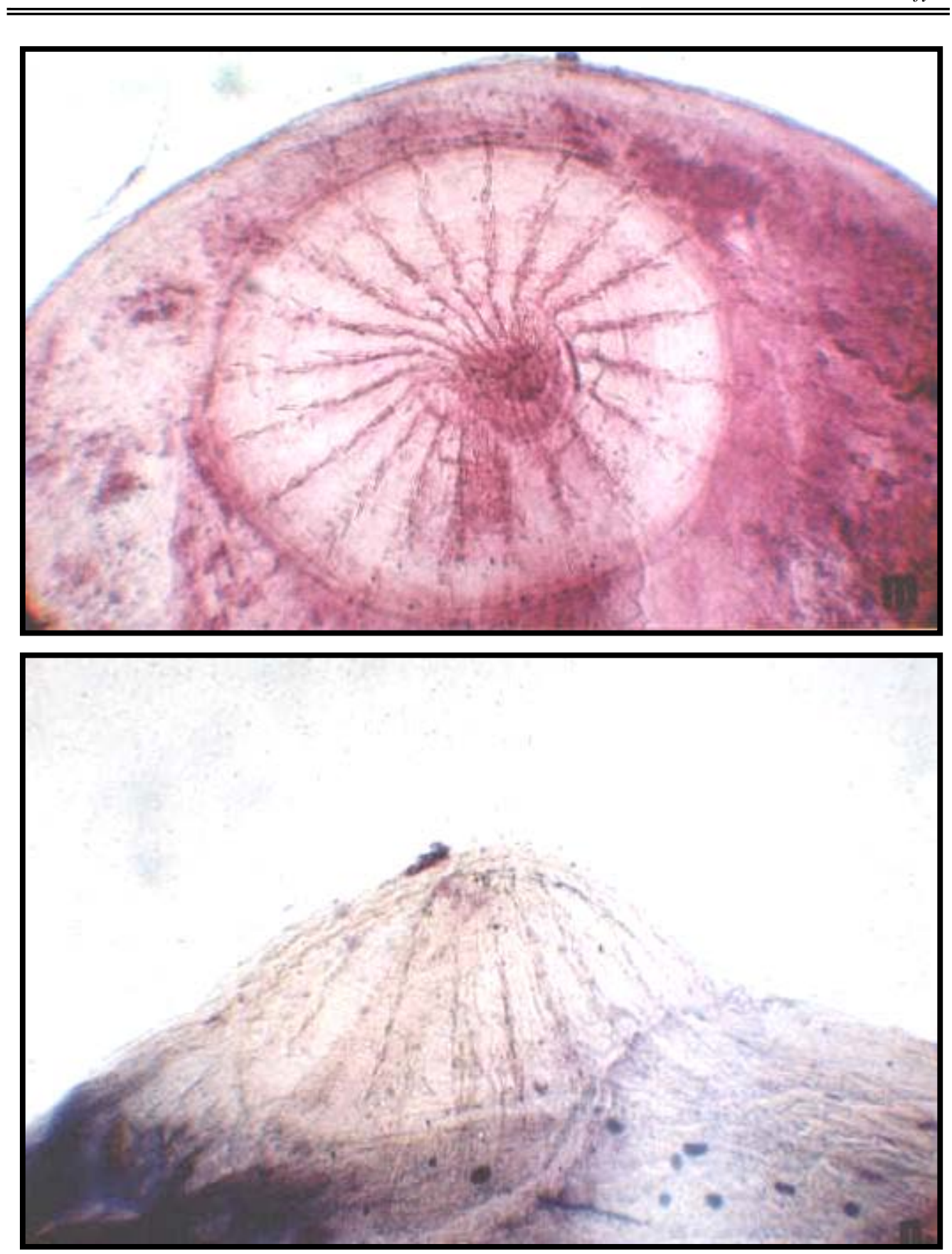

Fig (4): Typical arrangement of hooks in the apex of the proboscis of female (in a star shape or radially arranged). 

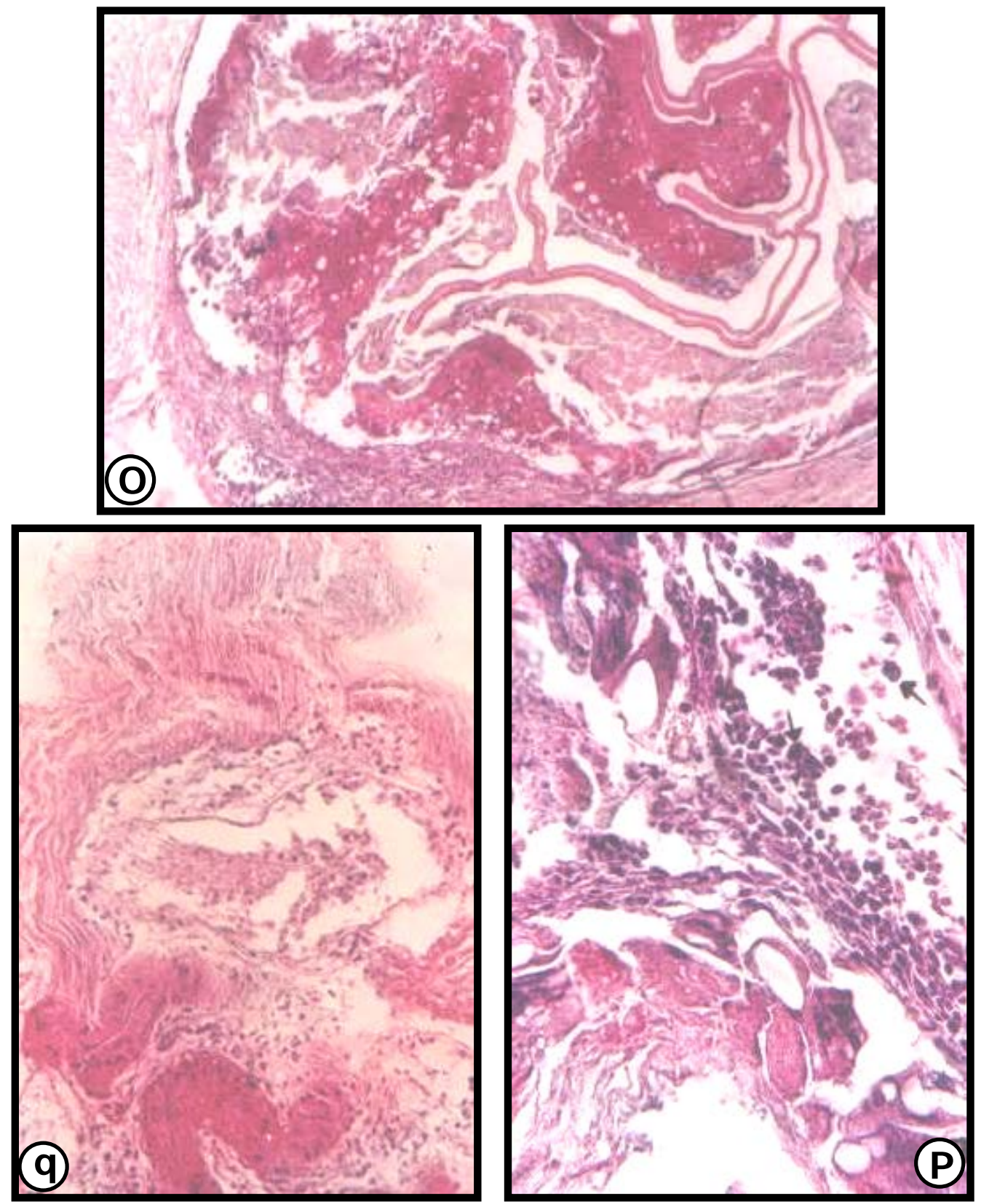

Fig (5): o- C.S. of the worm surrounded with dense connective tissue fibers. X200. p: Part of C.S. of the worm surrounded with inflammatory cells with giant cells $\mathrm{x} 400$. q: C.S. of the worm where penetration of the intestine occurred $\mathrm{x} 250$ ( $\mathrm{H}$ and $\mathrm{E})$. 

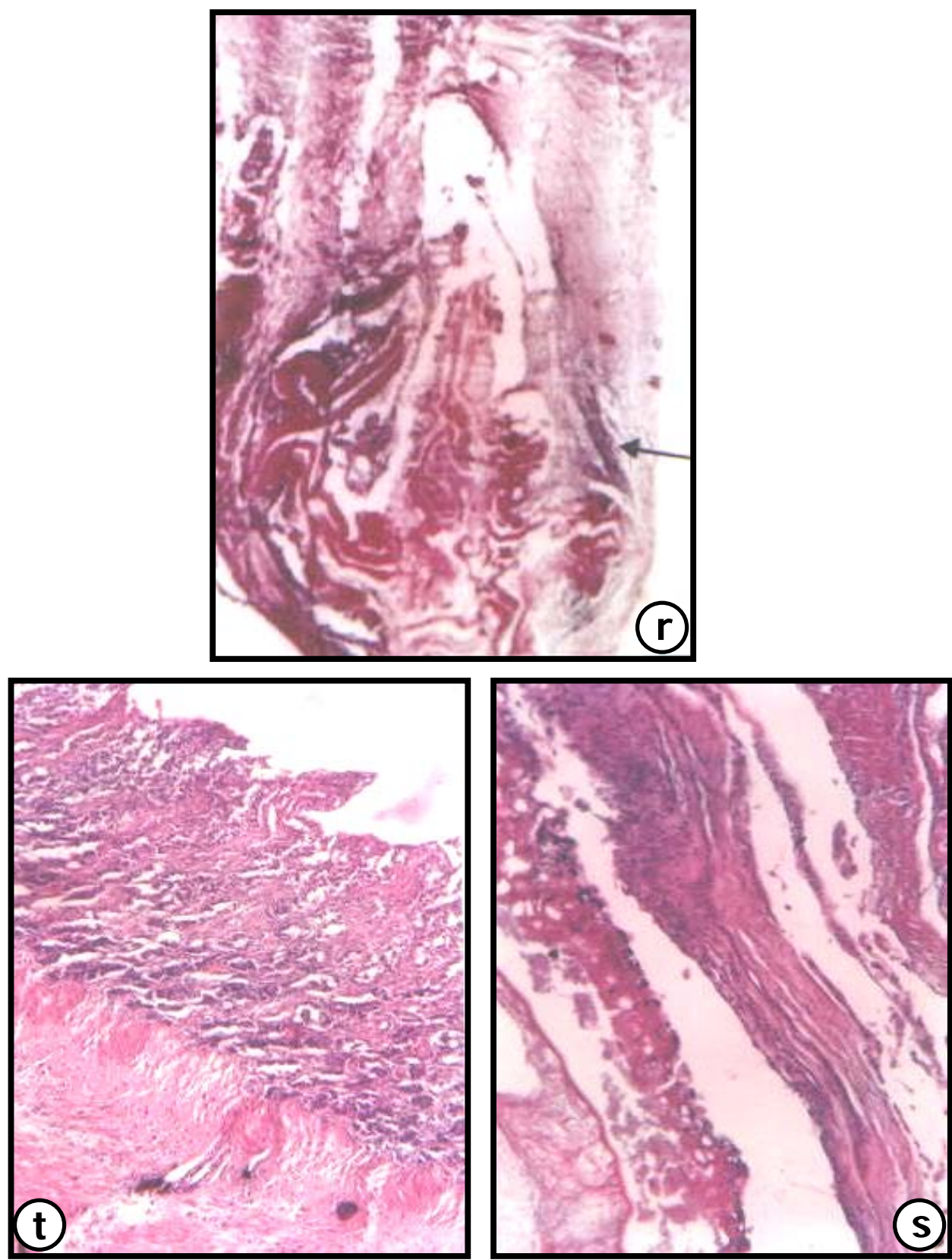

Fig (6): $r$ - C.S. of the worm where the trunk remains in the intestinal lumen $\mathrm{x} 200$. s: Erosion of intestinal epithelium where it is in contact with the trunk of the worm $\mathrm{x} 250$. $\mathrm{t}$ : Sloughing and shorten of the intestinal villi x250 (H and E). 

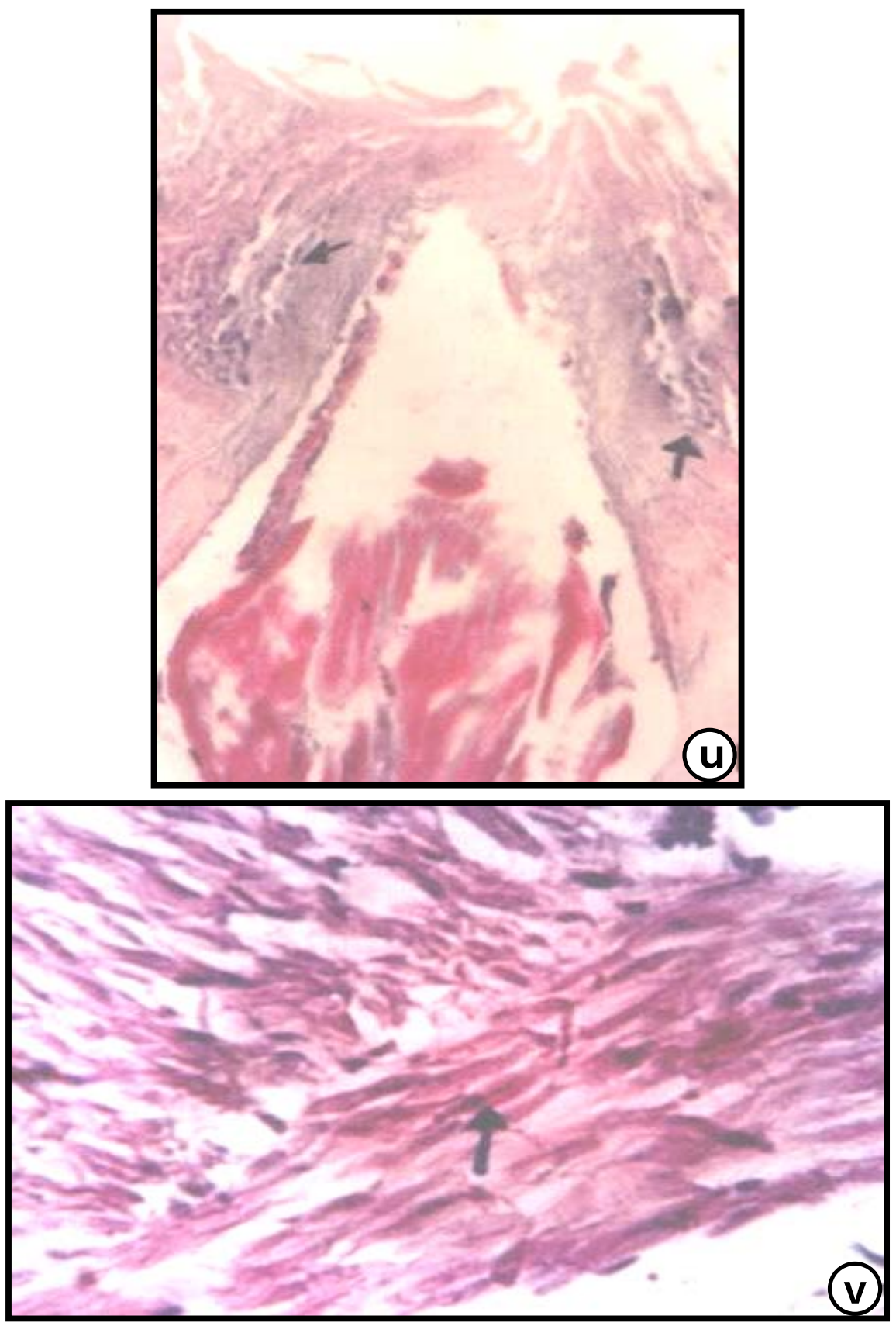

Fig (7): u-C.S. of presoma of Filicollis with focal areas of inflammatory cells $x$ 200.v: Giant cells of the muscles of presomal root x 650 (H \& E). 


\section{REFERENCES}

- Ash, L. R. and T. C. Orihel.(1987): A guide to laboratory procedures and identification. American Sociaty press.

- Ashmawy, K. I. And El- Sokkary M. Y. (1991): Morphobiological studies on Pseudoporrorchis species (Acanthocephela); infecting the Egyptian cuculus (Centropus Senegalenses Aegyptius ). Assiut. Vet. J. Vol. 25, No. 49.

- Atrashkevich, G.I. (1982): Filicollis trophimenkoi sp. n. (Acanthoce-phela; Poymorphidae) from anatidae in northwestern Chukotka (in Russian).Parasitologiya (leningr) 16:102106

- Carleton, E. M. (1987): Histological technique for normal and patho-logical tissues and identification for the parasites. $3^{\text {rd }} \mathrm{Ed}$., London, Oxford Univ., Press, N.Y., Tornto

- Dimitrova, Z. AND Genov, T. (1992): Acanthocephelans from some aquatic birds from Bulgarian Black Sea Coast. Folia Parasitologica. 39:3, 235 - 247.

- El-Seify, M. A. and Abd El- Fattah, A. M. (1996): Some studies on the helminth of wild birds in Kafr El- Sheikh Governorate, Egypt. $7^{\text {th }}$. Sci. Cong. 17 - 19 Nov. (1990) Fac.Vet.Med, Assiut Univ.

- Hayaunga,E.G.(1979): Observations on the intestinal pathology caused by three Caryophyllid tapeworms of the white sucker Catostomus Commersoni Lacepede. J. Fish Dis.2:239-248.

- Hegazy, A. (1978): The invertebrate parasites of wild birds in Egypt. Thesis Master Sci., Fac. Sci., Tanta University. 
- Loose,A.(1896):Recherches sur la fauna parasitaire la Egypt. Premiere Parize Mem. Inst. Egypt, 3: 1, 252.

- Luhe, M. (1911): Acanthocephelen. Brauer. Suswasserfauna Deutsch-ands. H. 16.

- McDonald,M.E.(1988):Key to Acanthocephela reported in waterfowl USA, Fishand Wildlife service,Washington D.C. Resource Publication 173.

- Melissa, J.; Donough, M.C. and Larry, N. (1981): Histopathology in rainbow Darter. Etheostoma Caeruleum, resulting from infections with the Acanthocephalans, Pomphorhynchus Bulbocolli and Acanthoceph-alus Dirus. J. Parasitology 67 (3): 403- 409.

- Meyer,A.(1931):Die Acanthocephalen des arktischen Gebietes. Fauna Arvtica ( Roemeru.Schaudinn) 6: 9-20.

- Nikishin, V.P.(2000): Nuclear secretion in giant muscle cells of Acan-thocephala Filicollis anatis. Tsitologiia 42 (5): 429 - 432.

- Petrochenko, V. I. (1956): Acanthocephela of domestic and wild animals. Vol. 1. Akad, Nauk. SSSR, Moscow, 435p. (inRussian)

- Petrochenko, V.I. (1958): Acanthocephela of domestic and wild animals. Vol. 2. Akad,Nauk.SSSR,Moscow 458 p. (in Russian)

- Petrochenko, V. I. (1971): Acanthocephela of domestic and wild animals. Vol. I. Izadatel stvo Academii Nauk S.S.S.R., Moscow, 1956 pp 456(English translation by Israel program for scientific translations, Ltd., 1971). 
- Petrova, K. and Vasilev, I. (1984): Acanthocephela of wild birds in Bulgaria Fauna, takasonomiya, I, ekologiya, na Khelminti- po-ptitsi, 185-187.

- Schmidt, G.D. (1969): Acanthocephela as agents of disease in wild mammals. Wildlife diseases 53, 10 pp.

- Selim,M.K.and El Kassaby,Aziza(1965): The occurance of Capillaria obsignata in the U .A. R. J. Arab. Vet. Med. Assoc., 25 (4): 225 - 236.

- Soulsby, E. J. L. (1968): Helminthes, Arthropods and Protozoa of domesticated animals (sixth edition of monnigs veterinary helminthol-ogy and entomology)Williams and Wilkins Company,Baltimore,U.S.A

- Soulsby, E. J. L.(1982): Helminths, Arthropods and Protozoa of domesticated animals. $7^{\text {th }}$. Edit, Bailliere Tindall, London 630- 645.

- Southwell, T. and Macfie (1925): On a collection of Acanthocephela in the Liverpool School of Tropical Medicine. Ann.Trop.Med.Parasit., 19: 141-184.

- Taraschewski, H. and Hofmann, U. (1991): Host - parasite interface of Filicollis anatis (Palaeacanthocephala) in domestic ducks. Diseases of Aquatic Organisms 11, 155-162.

- Taraschewski, H. (2000): Adv. Parasitol. V. 46. P 1-179.

- Van Cleave, H. J. (1920): Sexual dimorphism in the Acanthocephala. Transactions of the Illinois Academy of sciences 13, 280-292.

- Ward, H. L. (1956): Acanthocephala from shore birds of Egypt, with description of Medorronchus species. J. Parasit., 46: 611-61 
- Webester, J. D. (1948): A new Acanthocephalan from the sanderling. Tr. Am. Micr. Soc. 67: 66-69.

- Yamaguti, S. (1963): Systema Helminthum. Vol. V. Acanthocephela. Interscience John Wiley and sons, New York and London

در اسات مورفولوجية وباثولوجية على نوع من القيليكولس (شوكيات الر أس) المتطفل على بعض الطيور المائية في محافظة بور لون سعيد

م مدوح وجدي غطاس * ، مايسة محمود حنفي

"معهز بحوث صحة الحيوان - المعمل الفرعي بمحمية الجميل الطبيعية ببور سعيد. **قم الباثولوجيا- معهد بحوث صحة الحيوان - الدقى.

استهدفت هذه الدراسة التعرف على الديدان البالغة والغير بالغة للاكانسوسيفلا ذات الرأس الشوكية من نوع الفيليكولس والذي تم تجميعه من الأمعاء الدقيقة لبعض الطيور المائية من أنواع الغر ودجاج الماء والبط النهري (الحذف أو الثرشير) والتي تم اصطيادها من شواطئ بحيرة المنزلة المجاورة للحافظة بور سعيد ، مصر وذلك خلال الفترة من نوفمبر 2003 وحتى أبريل 20040 وقد وصلت نسبة الإصابة العامة بالطفيل في هذه الطيور إلى 35و2\% . وبدراسة الأوصاف الكاملة ومقاسات هذا الطفيل ومقارنته مع ما سبق وصفة من هذا النوع أكدت الدراسة انه يخص نوع من أنواع الفيليكولس الذي يصيب الطيور المائية. وقد سجل الطفيل لاول مرة في مصر واعتبرت شواطئ بحيرة المنزلة المجاورة لمحافظة بور سعيد بمصر منطقة تواجد جديدة لديدان الفيليكولس. وقد ثبت بالدراسة أن هناك تغييرات هستوباثولوجية حادة ناتجة عن الإصابة بهذه الطفيليات تتركز في تهنك الأنسجة الطلائية المبطنة لجدار الأمعاء الذي يمتد إلى الجزء العضلي بها مع وجود خلايا التهابية ونسيج ليفي حول الديدان (مقدمة الرأس، الجسم والمؤخرة) التي تخترق الأمعاء أو تحاول اختراقها , كذلك وجود زيادة في عدد الخلايا الإفرازية بجدار الأمعاء (في حالة وجود الطفيل). كما تلاحظ في كثير من الحالات 
المصابة وجود استحالة وتتكرس في الغدد الموجودة بجدار الأمعاء بالإضافة إلى وجود خلايا عضلية عملاقة في الجزء العضلي من الأمعاء. وتعتبر هذه الأنواع من الطيور المائية أن لها دورا هاما في نقل هذه الطفيليات وخاصة إلى بعض الأنواع من الطيور المستأنسة في بعض المحميات الطبيعية التي تهاجر إليها. 